\title{
Attendance and Information System using RFID and Web-Based Application for Academic Sector
}

\author{
Hasanein D. Rjeib \\ Faculty of Engineering \\ University of Kufa \\ Al-Najaf, Iraq
}

\author{
Nabeel Salih Ali, Ali Al Farawn, Basheer Al-Sadawi, \\ Haider Alsharqi \\ IT-RDC Center \\ University of Kufa \\ Al-Najaf, Iraq
}

\begin{abstract}
Recently, students attendance have been considered as one of the crucial elements or issues that reflects the academic achievements and the performance contributed to any university compared to the traditional methods that impose time-consuming and inefficiency. Diverse automatic identification technologies have been more in vogue such as Radio Frequency Identification (RFID). An extensive research and several applications are produced to take maximum advantage of this technology and bring about some concerns. RFID is a wireless technology which uses to a purpose of identifying and tracking an object via radio waves to transfer data from an electronic tag, called RFID tag or label to send data to RFID reader. The current study focuses on proposing an RFID based Attendance Management System (AMS) and also information service system for an academic domain by using RFID technology in addition to the programmable Logic Circuit (such as Arduino), and web-based application. The proposed system aims to manage student's attendance recording and provides the capabilities of tracking student absentee as well, supporting information services include students grading marks, daily timetable, lectures time and classroom numbers, and other student-related instructions provided by faculty department staff. Based on the results, the proposed attendance and information system is time-effective and it reduces the documentation efforts as well as, it does not have any power consumption. Besides, students attendance RFID based systems that have been proposed are also analyzed and criticized respect to systems functionalities and main findings. Future directions for further researchers are focused and identified.
\end{abstract}

Keywords-Student attendance; Attendance Management System (AMS); information service; RFID; IoT; radio-frequency identification; Arduino

\section{INTRODUCTION}

Information Technology (IT) has played a significant role in developing several aspects in academic sectors and domains such as student monitoring and management systems [1], [2]. Therefore, it is a critical subject to tracking and manages student's attendance in school, college, and university environment. Since it can be helped to urge students to attend on time, amend the efficiency of the learning, increase learning grade, and finally boosting and improving the education level [3], [4]. Calling student's name or taking student's signature are two traditional methods for tracking the attendance of the students in the classroom and they were more time-consuming [5], [6]. Nevertheless, the academic performance influenced by student's presentation. So, there is a need to manage the student attendance records automatically by using information technology management system in a faculty to assist the maintaining attendance [1], [7]. Hence, the attendance systems can be useful to reduce administrative complexity and cost rather than increase the efficiency of the education [8], [9]. In the digital era, technologies have been developed and emerged recently, and that could change the future of sciences to affect people everyday life such as Wireless Sensor Networks (WSNs) [10]. Biometrics techniques are used to verify identification through their characteristics like face recognition, signatures, fingerprint, voice recognition, irises, barcode, Bluetooth, Near-Field Communication (NFC), RFID and so on [11], [8]. Identification, tracking, and counting are different applications for these technologies based attendance systems. RFID is an automation technology used to identifying and positioning an object [12]. Healthcare industry, financial institutions, cars, books, mobile phones, computer equipment, are several applications that they used RFID technology to positioning and managing people, assets, and inventory [11].

Diverse studies have been conducted to propose students attendance system to manage, record, and track the presenting of the students in an academic sector. These systems used several technologies that are ranging from Quick Response (QR) code, Ethernet and Wi-Fi interfaces to RFID with Liquid Crystal Display (LCD), or General Packet Radio Service (GPRS). Related works proposed and developed student system attendance such as, in 2012, Patel et al. proposed student attendance system based on RFID technology to compact lightweight and inexpensive used to record students' attendance and displayed on the screen and integrated good system [13]. Likewise, Yuru et al., 2013 is presented an integrated student attendance system which based on RFID technology and the hardware node of the system, and the development processes of related application have been presented in details [1]. In addition to, student's attendance system with RFID designed by Kurniali et al., 2014 that collected web-based with RFID readings and the main findings of the proposed system was to reduce or eliminate the manual labour requirements. As well as, the system provided faster processes, less inventory, fewer efforts, and better quality via providing direct cost savings while it caused some technical issues and slow system deployment [7]. Furthermore, development of a student attendance 
management system using RFID and face recognition proposed by Patel and Priya in 2014. The developed system log contained an RFID tag ID and captured the image by a camera [11]. On the other hands, QR Code technology proposed by Miran in 2014 to develop and check the student's attendance system at the University of Sulaimaniyah. The advantage of the conducted system is to determine students absentee rate regularly, but it required each student has a smartphone that is capable of image capturing which considered as slow method because the teacher read the names over the phone and then sent to the database [14]. While NFC technology with the embedded camera on a mobile device that proposed by Dae in 2014 to develop attendance system. The conducted system recorded students' attendance by using Bluetooth, but the limitation of the proposed system is that the phones must have Bluetooth technology within the operating system [15].

Several traditional methods for student's attendance management imposed time consumption, increasing workforce requirements, and duplication of the efforts respectively. On the other hands, these mechanisms were boosted and improved the education level and amended the efficiency of the learning in the academic sector such as college or university. In this article, a student attendance management and information service system is proposing. The system prevents to manage student's records and provides the capabilities of tracking student attendance, supporting an information service about student grading marks, daily timetable, lectures time and classroom numbers, and other student-related instructions that provided by faculty department staff by using RFID technology with web-based application hybrid scheme. Students attendance RFID based systems that have been proposed are also analyzed and criticized respect to systems functionalities and main findings to identify and focus on the critical and vital systems or technology that need further attempts by future researchers through which the advantages of high efficiency and effectiveness can be obtained. The system functionality include data management, tracking students, sending reports, monitoring records, maintenance records, and finally providing information services. The remainder of the article structures as follows. Section 2 discusses the methodology and the materials used in the proposed system architecture. Section 3 provides all steps of the implementation methods and measures, and Section 4 presents the results. Reviews and analyzes the attendance systems that have been conducted before based on several metrics in Section 5. The conclusions, remaining challenges, and future directions for this system are presented in Section 6.

\section{ATTENDANCE AND INFORMATION SYSTEM ARCHITECTURE}

In this section, the system will be presented and described, also, the equipment used for developing and designing the electronic circuit that includes software and hardware requirements will be displayed in Fig. 1, as well, methods and implementation steps to conduct and monitor the student attendance and information system. The proposed circuit aims to investigate student's services that provide presence and information services based on the internet of things applications and technologies by literature review that gives an overview of what has been done. To implement the presented system, hardware and software components are required to establish the implementation process that has been chosen based on three criteria and metrics such as, cost, availability, and easy programming. The RFID reader connected to Arduino Uno microcontroller device which is open circuit system by pins and Ethernet shield device that connected with Arduino board. The Arduino circuit sends the signal to a server-based via using Ethernet cable as well using Wamp server, PHP and MySQL for the server to archive the student information attendance records and present student records via a using web-based application like a computer at the front end of the attendance records and information management end to present students attendance records and to students registration via the staff in a faculty. Besides, the proposed system provides information service for students by displaying their information such as grading marks, daily timetable, lecture time, classroom number, and other related instructions via LCD screen. These information services demonstrated shown in the block diagram for the proposed system in Fig. 1.

\section{SYSTEM IMPLEMENTATION}

\section{A. Phase One (Student Attendance and Information Management Phase)}

This section gives a clear description of all processes of the system. In this stage, all steps and procedures for conducting the student attendance management part of the current system are described and presented in Fig. 2. The student scans (RFID Tag) into (RFID Reader) where (RFID Reader) reads the (ID) for the student in particularly via student ID (Reading Process) and then transfer information via Arduino board (Microcontroller Process) and Ethernet shield (Transmission Process) to send data to the Wamp server (MySQL and PHP) by wired (Server Process) to record, manage, and display student attendance records by a webbased application.

\section{B. Phase Two (Student Information Service Phase)}

In this phase, the RFID reader reads the student's ID (Reading Process), Arduino UNO (Microcontroller process) is used to transfer student's information to the Wamp server through the cable via Ethernet shield card (Transmission Process). Server (MySQL and PHP) is used to identify student ID and to send student's information to the screen (see Fig. 3). The student scans the (RFID Tag) to the (RFID Reader) where (RFID Reader) reads (ID) for the student and then send it through Arduino board and to the server side (MySQL and PHP) where it searches for the ID of the particular student and fetches his data from database then the information can be presented on the screen or LCD (see Fig. 3). These data contain information regarding the student such as student name, stage, and group as well as daily timetable that encompasses classroom number, lecture time, subject name, and lecturer name. As well, the system presents all instructions and roles which are sent by the administrator to a particular student (see Fig. 4). 


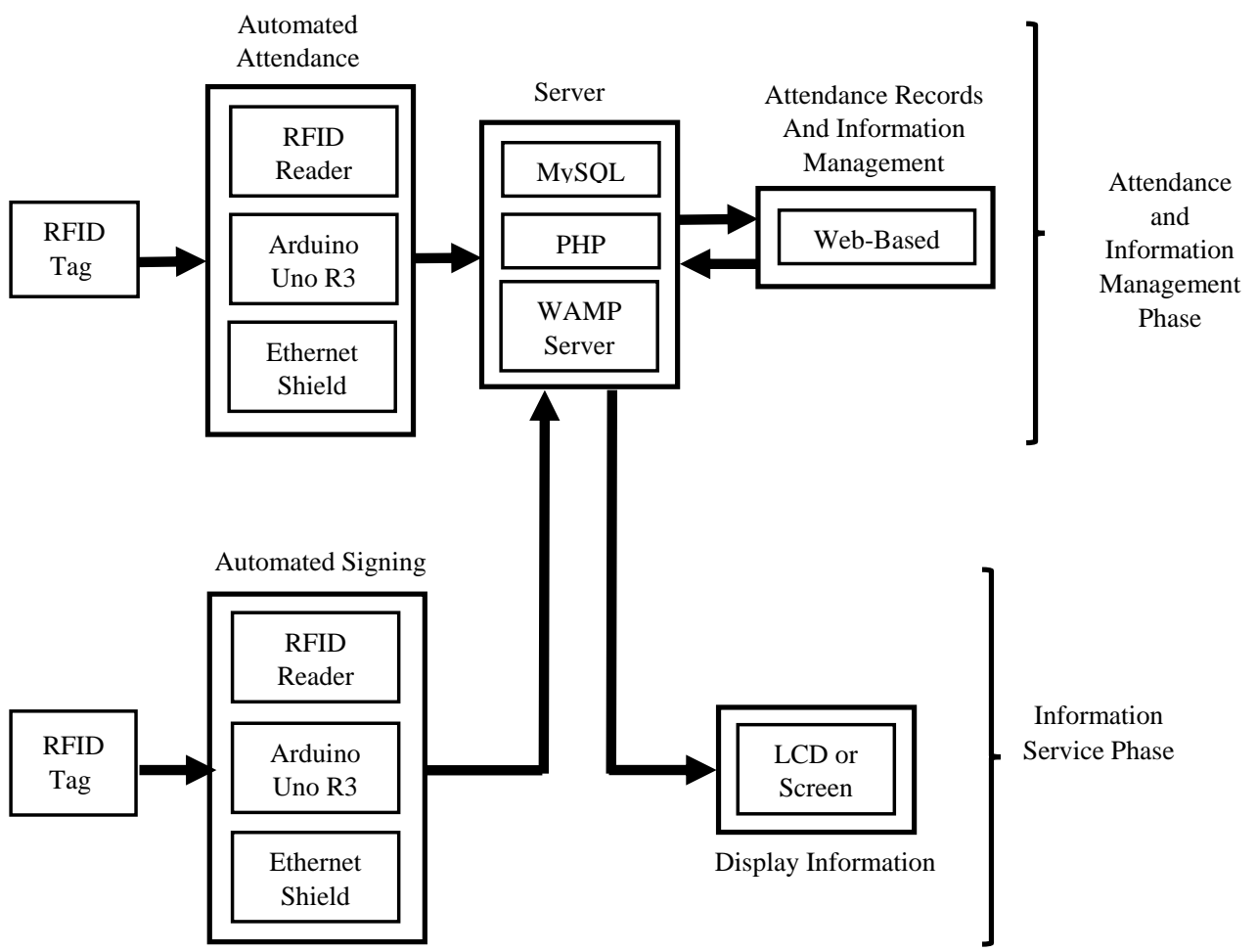

Fig. 1. Block diagram for the proposed system architecture.

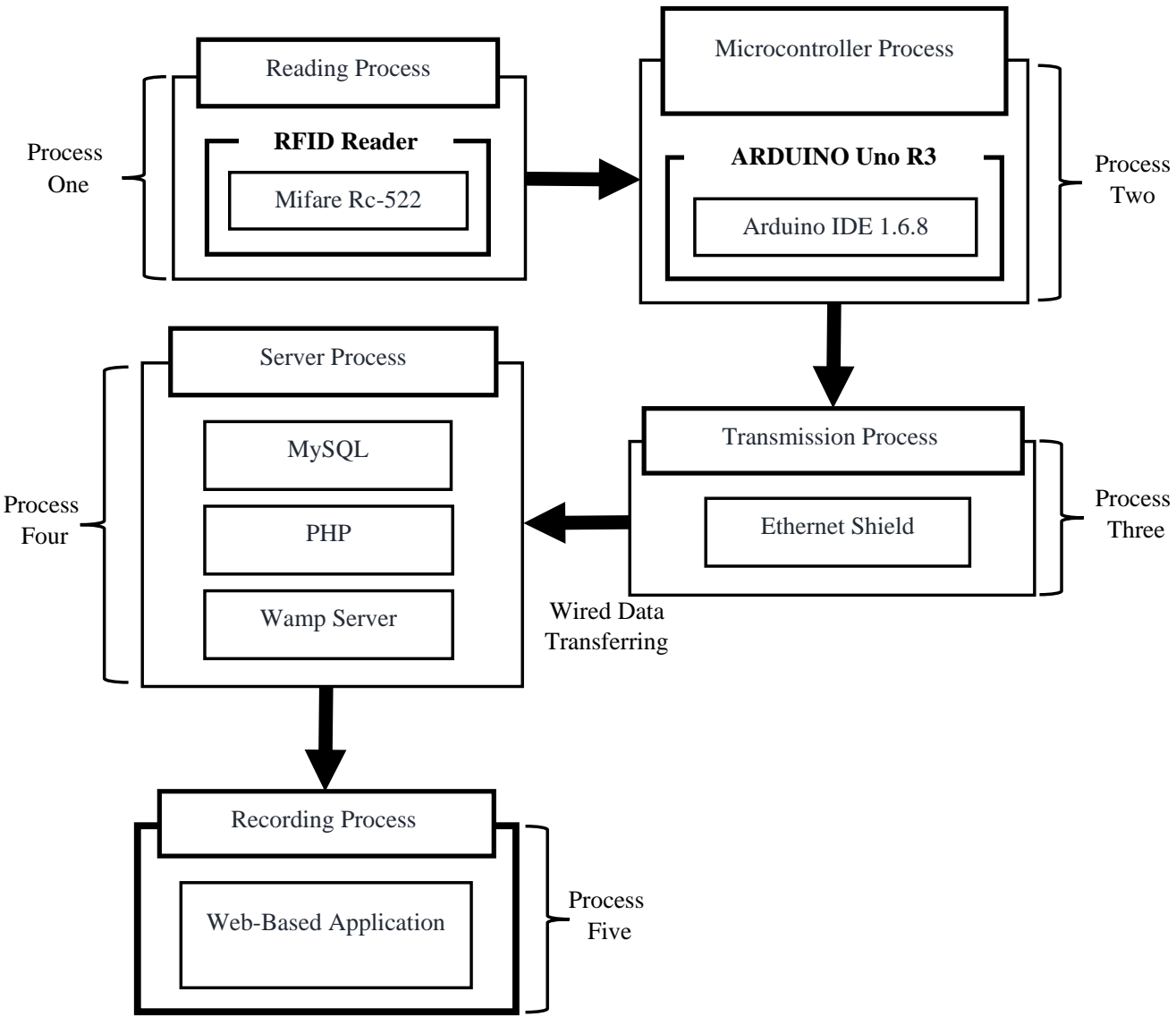

Fig. 2. Procedures steps for student attendance and information management phase. 


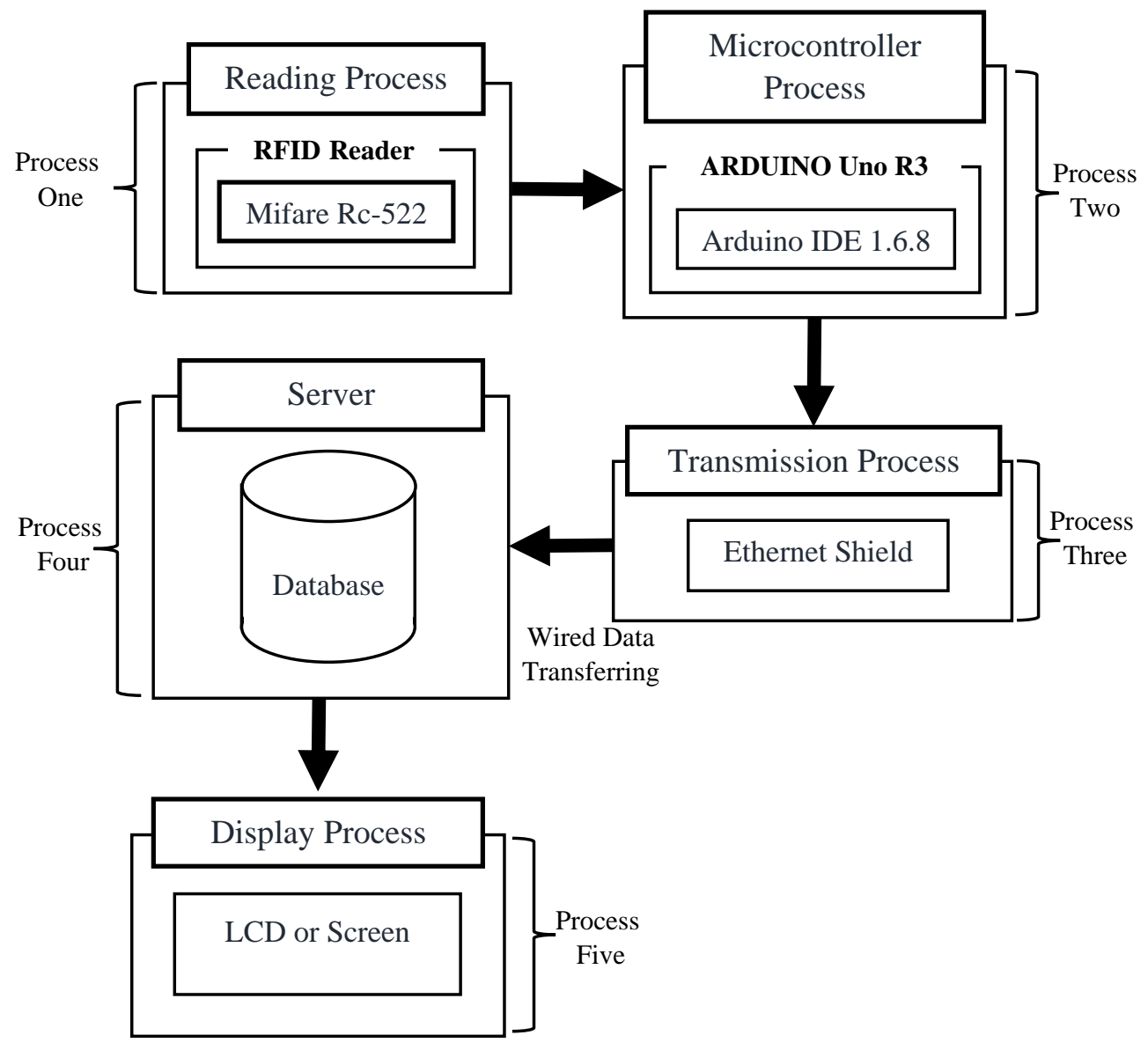

Fig. 3. Procedure steps for the student information service phase.

\begin{tabular}{|c|c|c|c|}
\hline \multicolumn{3}{|c|}{ Student Information Service } \\
\hline
\end{tabular}

Fig. 4. Student information service displayed screen. 
The parts of RFID reader is connected to the Arduino device's pins (the first pin to $3.3 \mathrm{v}$, the second (RESET) is connected to D9, the third pin to the ground, the four (NC) is not used, the fifth pin (MISO) is connected to (D12), the sixth (MOSI) is connected to (D11), the seventh (SCK) connects to (D13) and the last pin (SAD) connects to (D10)). Ethernet device is setup with Arduino device. The signal that input to the Arduino is processed inside it. Then, the signal is sent to the server via Ethernet cable. MySQL is used to archive the student records and information in which it will be shown by using PHP and Arduino IDE with the aid of the graphical user interface for student information via web-based application as we demonstrated in Fig. 4.

\section{RESUlTS AND DISCUSSION}

The proposed system is achieving two aims, the first objective is to register, record, and manage a student attendance using RFID tag, and the second aim is to provide student information service such as timetable, lecture time and classroom number, and other student-related data that displayed in screen or LCD. The traditional method for taking student absence report is usually done by using paper-work and handwriting on the advertisement wall. Hence, paperwork method consumes workforce requirements, duplication of the efforts, and imposes time-consuming and inefficiency.
Table I presents and lists a comparison between traditional attendance system (paper-work) and the proposed system based on different parameters [8], [16]-[20].

On the other side, several types of automatic attendance systems such as a barcode, magnetic stripe, biometrics, and RFID attendance system are suited for different needs and requirements. To differentiate between the most standard types of automatic attendance systems, Table II discusses and describes the current generation of the common automated attendance registration systems with concerning different parameters [11], [17], [19], [21]-[25].

Traditional technology such as QR code, Barcode, and Magnetic stripe imposed a long time for registration and errorprone, low data accuracy and resources, artificial identification, traditional manual management and individual personnel statistics for attendance management records, and it is not eco-friendly due to paper attendance cards and documentation. While, the proposed system based on RFID technology can achieve several advantages such as userfriendliness, affordability, security, flexibility, high resources and data accuracy, automatic and tag identification without human interference, indicating work status and generating the attendance report automatically, and it does not need to spend extra time and efforts.

TABLE I. COMPARISON BETWEEN TRADITIONAL SYSTEM AND PROPOSED SYSTEM

\begin{tabular}{|c|c|c|c|c|c|c|c|c|c|}
\hline Parameters & $\begin{array}{l}\text { Human } \\
\text { Interference }\end{array}$ & $\begin{array}{l}\text { Time- } \\
\text { Consuming }\end{array}$ & $\begin{array}{l}\text { Efforts } \\
\text { Spend }\end{array}$ & Speed & $\begin{array}{l}\text { System } \\
\text { Security }\end{array}$ & $\begin{array}{l}\text { Resources } \\
\text { (Documents) }\end{array}$ & $\begin{array}{l}\text { Data } \\
\text { Accuracy }\end{array}$ & $\begin{array}{l}\text { Registration } \\
\text { Time }\end{array}$ & $\begin{array}{l}\text { User } \\
\text { Friendly }\end{array}$ \\
\hline $\begin{array}{l}\text { Traditional } \\
\text { System }\end{array}$ & Yes & $\begin{array}{l}\text { More than } 5 \\
\text { minutes }\end{array}$ & Yes & $\begin{array}{l}\text { Slow } \\
\text { (human) }\end{array}$ & More vulnerable & $\begin{array}{l}\text { More paper } \\
\text { work }\end{array}$ & Low & $\begin{array}{l}\text { More than } 8 \\
\text { minutes for } \\
\text { each student }\end{array}$ & No \\
\hline $\begin{array}{l}\text { Proposed } \\
\text { System }\end{array}$ & No & $\begin{array}{r}\text { Less than } 2 \\
\text { minutes }\end{array}$ & No & $\begin{array}{r}\text { High } \\
\text { (computer) }\end{array}$ & $\begin{array}{r}\text { Authenticated } \\
\text { persons only }\end{array}$ & $\begin{array}{l}\text { Only one } \\
\text { electronic } \\
\text { record }\end{array}$ & $\begin{array}{l}\text { High } \\
\text { Accuracy }\end{array}$ & 1-2 minute & Yes \\
\hline
\end{tabular}

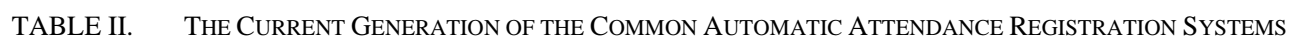

\begin{tabular}{|c|c|c|c|c|}
\hline Parameters & Barcode & Magnetic Stripe & Biometric & RFID \\
\hline Resources and data Accuracy & High & High & High & Very High \\
\hline Data Density & Low & Low & High & Very High \\
\hline Purchasing Cost & Low & Low & High & Low \\
\hline Speed and Security & High & High & High & High \\
\hline Influence Covering the Data carrier & $\begin{array}{l}\text { Total failure of } \\
\text { system }\end{array}$ & Total failure of system & $\begin{array}{l}\text { complete failure as } \\
\text { system works on } \\
\text { contact Not }\end{array}$ & No control \\
\hline Functionality & Wide & Wide & Wide & Wide \\
\hline Operating Cost & Low & Low & High & Low \\
\hline Power Consumption & High & High & Moderate & Moderate \\
\hline Influence Direction of reader and Data Carrier & $\begin{array}{l}\text { Failure - if no line-of- } \\
\text { sight communication }\end{array}$ & $\begin{array}{l}\text { Failure - if no slot- of } \\
\text { communication }\end{array}$ & $\begin{array}{l}\text { Not applicable as direct } \\
\text { contact is needed }\end{array}$ & $\begin{array}{l}\text { No influence as data are } \\
\text { transferred via radio } \\
\text { waves }\end{array}$ \\
\hline $\begin{array}{l}\text { Distance of Reader and Data Carrier ( in } \\
\text { Centimeters) }\end{array}$ & 0-50 cm Direct & Direct contact & Direct contact & $\begin{array}{l}0-6 \mathrm{~m} \text { depending on the } \\
\text { frequencies used }\end{array}$ \\
\hline
\end{tabular}




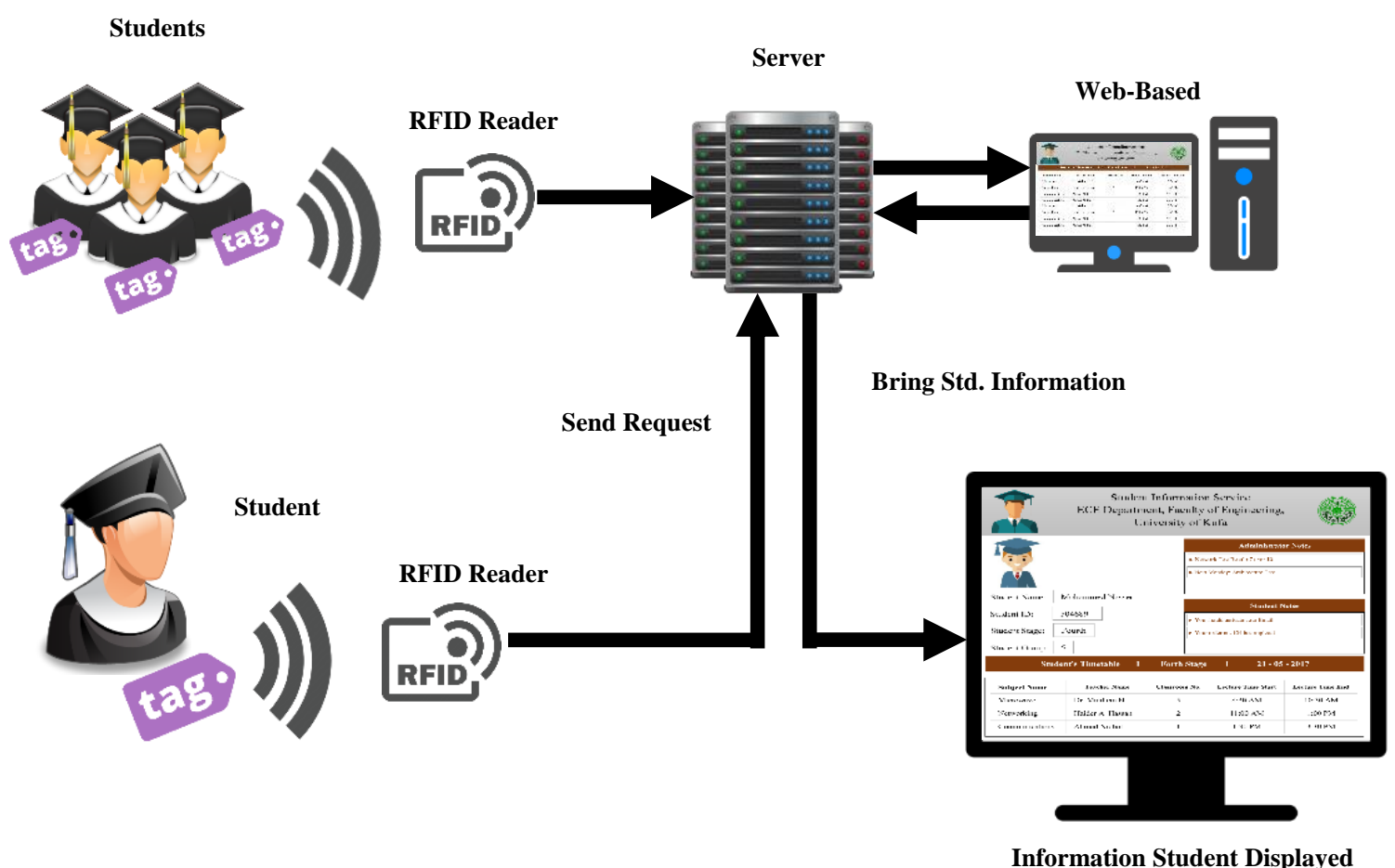

Fig. 5. Flowchart of the proposed attendance and information service system.

The proposed system provides facilities for both students and staff by reducing time to take absence, as well as, providing a database system that holds all the student's information (i.e. there is no need for archiving shelf and paper works). The system introduces facilities for registering new students, sending reports and warnings to them; displaying results for tests and homework, and other notifications such as staff appointment schedule, lecture cancelling, and so on. From the student perspective, the student will be informed of all the required information via the screen, as well as the absence report warning if any, also the system provide student attendance mechanism. From the staff or faculty management perspective, it would be much easier to track the student report by just clicking the required student name to add or edit specific information or to add warning and notification, and there is no need to check and review dozens of papers to collect information about the students. As well as, the system provides a weekly statistical report regarding student absences which is got by the computer-based application. Fig. 5 shows the two phase's flowchart of the proposed attendance and information system.

\section{COMPARISON OF THE PREVIOUS RFID BASED ATTENDANCE SYSTEMS BASED ON CRITICAL REVIEW}

This section presents a critical review of the works and attempts by previous authors that implemented Attendance Management System (AMS) in an academic sector in details and highlights their systems functionality, schemes and main findings. The feature of the proposed system includes several characteristics such as data management, tracking students, sending reports, monitoring records, maintenance records, and finally providing information services. The section conceptually provides insights into the standard (previous and existing) works. These works, which have been conducted from 2013 until 2017, were aimed to determine and eliminate the lacks for the traditional methods and techniques regarding RFID based systems. Table III summarizes the functionality metrics of the previous systems in practice. We use two different types of markings to indicate system functionality. The symbol ' $\checkmark$ ' denotes that the system has one of the metrics. Conversely, the symbol ' $\boldsymbol{x}$ ' signifies that a system does not have any metrics of functionality. We assess each system concerning its functionality based on the functionality of the proposed systems like data management, tracking students, sending reports, monitoring records, maintenance records, and finally providing information services. As we have shown in Table III, several results are found through comparing attendance management systems. We compared the functionality for each system based on the following criteria or metrics:

1) Does the system manage the student's attendance data or records?

2) Does the system have any technology to track the student's position and location?

3) Does the system have to send notifications or reports services?

4) Does the system monitor the performance of the students via monitoring the attendance student records?

5) Does the system maintain student attendance records and data when an error occurred?

6) Does the system provide any information service for students which displayed via the screen? 
TABLE III. COMPARISON OF THE PREVIOUS STUDIES FOR RFID BASED ATTENDANCE SYSTEMS

\begin{tabular}{|c|c|c|c|c|c|c|c|}
\hline \multirow[b]{2}{*}{ Author (s) } & \multicolumn{6}{|c|}{ System Functionality } & \multirow[b]{2}{*}{ Main Findings } \\
\hline & $\begin{array}{l}\text { Data } \\
\text { Management }\end{array}$ & $\begin{array}{l}\text { Tracking } \\
\text { Students }\end{array}$ & $\begin{array}{l}\text { Sending } \\
\text { Reports }\end{array}$ & $\begin{array}{l}\text { Monitoring } \\
\text { Records }\end{array}$ & $\begin{array}{l}\text { Maintenance } \\
\text { Records }\end{array}$ & $\begin{array}{l}\text { Information } \\
\text { Services }\end{array}$ & \\
\hline $\begin{array}{l}\text { Yuru et al., } \\
2013[1]\end{array}$ & $\checkmark$ & $x$ & $x$ & $x$ & $x$ & $x$ & $\begin{array}{l}\text { Designed an attendance checking system of } \\
\text { class based on embedded of ARM and RFID } \\
\text { technology. }\end{array}$ \\
\hline $\begin{array}{l}\text { Yadav\& Nainan, } \\
2014 \text { [26] }\end{array}$ & $\checkmark$ & $\checkmark$ & $\checkmark$ & $\checkmark$ & $x$ & $x$ & $\begin{array}{l}\text { An automatic attendance management } \\
\text { system presented for students and teachers as } \\
\text { well using GSM to sending notifications to } \\
\text { parents. }\end{array}$ \\
\hline $\begin{array}{l}\text { Arbain et al., } 2014 \\
\text { [27] }\end{array}$ & $\checkmark$ & $x$ & $x$ & $\checkmark$ & $x$ & $\checkmark$ & $\begin{array}{l}\text { Proposed an attendance system to record and } \\
\text { manage student attendance automatically in } \\
\text { the lab by using RFID-ARDUINO approach } \\
\text { in web-based laboratories settings. }\end{array}$ \\
\hline $\begin{array}{l}\text { Tiwari et al., } 2014 \\
\text { [28] }\end{array}$ & $\checkmark$ & $\checkmark$ & $x$ & $\checkmark$ & $\checkmark$ & $\checkmark$ & $\begin{array}{l}\text { Conducted GPRS based student attendance } \\
\text { system which it can be easily accessed by } \\
\text { the lecturers via the web to check and } \\
\text { monitor student attendance recording. }\end{array}$ \\
\hline Kurniali, 2014 [7] & $\checkmark$ & $x$ & $x$ & $x$ & $x$ & $x$ & $\begin{array}{l}\text { Developed a student attendance management } \\
\text { system by using RFID with a web-based } \\
\text { approach to managing student's attendance } \\
\text { in an Indonesian higher education institution. }\end{array}$ \\
\hline $\begin{array}{l}\text { Pranali et al., } 2015 \\
\text { [29] }\end{array}$ & $\checkmark$ & $\checkmark$ & $\checkmark$ & $\checkmark$ & $x$ & $x$ & $\begin{array}{l}\text { Adopted and developed an attendance } \\
\text { monitoring system based on Mifare } \\
\text { technology and server-based to tracking and } \\
\text { positioning students in campus settings. }\end{array}$ \\
\hline $\begin{array}{l}\text { Farpat et al., } 2015 \\
{[30]}\end{array}$ & $\checkmark$ & $x$ & $\checkmark$ & $x$ & $\checkmark$ & $x$ & $\begin{array}{l}\text { Managed student's attendance via proposing } \\
\text { an automatic computing system in } \\
\text { classrooms by using RFID technology. }\end{array}$ \\
\hline $\begin{array}{l}\text { Shengli et al., } \\
2015 \text { [16] }\end{array}$ & $\checkmark$ & $x$ & $x$ & $x$ & $x$ & $x$ & $\begin{array}{l}\text { Conducted automatic attendance system } \\
\text { based on RFID card connected to Arduino } \\
\text { microcontroller via the real-time database } \\
\text { environment to manage the employee's } \\
\text { attendance in an enterprise. }\end{array}$ \\
\hline $\begin{array}{l}\text { Kuriakose \& } \\
\text { Vermaak, } 2015 \\
{[21]}\end{array}$ & $\checkmark$ & $x$ & $x$ & $x$ & $x$ & $x$ & $\begin{array}{l}\text { Proposed an automate attendance } \\
\text { registration system by using Java-based } \\
\text { RFID technology to monitor, management } \\
\text { students attendance at the Central University } \\
\text { of Technology, South Africa. }\end{array}$ \\
\hline $\begin{array}{l}\text { Praveen Kumar } \\
\text { and Mani Kumar, } \\
2015 \text { [31] }\end{array}$ & $\checkmark$ & $x$ & $\checkmark$ & $x$ & $x$ & $x$ & $\begin{array}{l}\text { Presented attendance management system } \\
\text { based on RFID and Internet of Things (IoT) } \\
\text { applications which can be accessed from } \\
\text { anywhere and stored attendance records in } \\
\text { the cloud and sending SMS to several smart- } \\
\text { phones. }\end{array}$ \\
\hline $\begin{array}{l}\text { Srinidhi \& Roy, } \\
2015 \text { [32] }\end{array}$ & $\checkmark$ & $\checkmark$ & $\checkmark$ & $\checkmark$ & $\checkmark$ & $\checkmark$ & $\begin{array}{l}\text { Developed and adopted an automation } \\
\text { attendance monitoring and management } \\
\text { system based on web-based applications } \\
\text { using RFID and biometrics technologies for } \\
\text { an academic college and university } \\
\text { environment with safe and secure system } \\
\text { advantages. }\end{array}$ \\
\hline $\begin{array}{l}\text { Ya'acob et al., } \\
2016 \text { [33] }\end{array}$ & $\checkmark$ & $x$ & $x$ & $x$ & $\checkmark$ & $\checkmark$ & $\begin{array}{l}\text { RFID Efficient student attendance } \\
\text { management system presented with a web } \\
\text { portal to reduce the time of taking the } \\
\text { attendance compared with the traditional } \\
\text { method. }\end{array}$ \\
\hline Proposed System & $\checkmark$ & $\checkmark$ & $\checkmark$ & $x$ & $\checkmark$ & $\checkmark$ & $\begin{array}{l}\text { The system provides attendance managing } \\
\text { records to evaluating their performance as } \\
\text { well support an information services for } \\
\text { students and faculty staff. }\end{array}$ \\
\hline
\end{tabular}


The answers to these questions are summarized in Table III. Based on Table III, there are several results regarding previous systems functionality such as all of the proposed attendance systems have data management of their records. While, [26], [28], [29], [32], and the proposed system is providing tracking students in their school, college or university to improve their student performance. Diverse systems have generating information reports for students or sending notifications to the parents or lecturers and so on like [26], [29]-[32], and the proposed system. A few of the proposed attendance systems have monitored and maintained records as we see in studies [28] and [32]. However, [26], [27], and [29] have monitored their attendance records whereas [30], [33], and the proposed system have maintained their attendance records. Four of the previous AMS have information services functionality such as [27], [28], [32], [33], and the proposed system.

\section{CONCLUSION AND FUTURE WORKS}

A student attendance and information system are designed and implemented to manage student's data and provide capabilities for tracking student attendance, grading student marks, giving information about timetable, lecture time, room number, and other student-related information. Also, the proposed system provides easiness for the staff where there is no need for extra paper works and additional lockers for saving data. Results achieved the innovation of developing the system proved reliable to support the attendance management system for an academic sector in the usage of the RFID technology and microcontroller board. It can be considered as a successful implementation. We found two general trends in the results of the comparison study in Section 5. Two of the proposed AMS have most of the system functionality criteria which are Tiwari et al., 2014 [28] and the proposed system. While, the AMS which presented by Srinidhi and Roy, 2015 [33] have all of the system functions. Two primary goals for future directions, the first goal is to extend the proposed system to include staff information as well. The second one is to extend the system to encompass more than one faculty with the insertion of face detection mechanism in the attendance monitoring system to control card replacements among different students.

\section{REFERENCES}

[1] Yuru, Z., Delong, C., \& Liping, T. (2013). The Research and Application of College Student Attendance System based on RFID Technology. International Journal of Control and Automation, 6(2), 273282.

[2] Sunehra, D., \& Goud, V. S. (2016, October). Attendance recording and consolidation system using Arduino and Raspberry Pi. In Signal Processing, Communication, Power and Embedded System (SCOPES), 2016 International Conference on (pp. 1240-1245). IEEE.

[3] Sayanekar, P., Rajiwate, A., Qazi, L., \& Kulkarni, A. (2016). Customized NFC enabled ID card for Attendance and Transaction using Face Recognition. International Research Journal of Engineering and Technology, 3(9), pp. 1366- 1368.

[4] Noor, S. A. M., Zaini, N., Latip, M. F. A., \& Hamzah, N. (2015, December). Android-based attendance management system. In Systems, Process and Control (ICSPC), 2015 IEEE Conference on (pp. 118-122). IEEE.

[5] Kohalli, S. C., Kulkarni, R., Salimath, M., Hegde, M., \& Hongal, R. (2016). Smart Wireless Attendance System. International Journal of Computer Sciences and Engineering, 4(10), pp. 131-137.
[6] Jacob, J., Jha, K., Kotak, P., \& Puthran, S. (2015, October). Mobile attendance using Near Field Communication and One-Time Password. In Green Computing and Internet of Things (ICGCIoT), 2015 International Conference on (pp. 1298-1303). IEEE.

[7] Kurniali, S. "The Development of a Web-Based Attendance System with RFID for Higher Education Institution in Binus University." EPJ Web of Conferences. Vol. 68. EDP Sciences, 2014.

[8] Walia, H., \& Jain, N. (2016). Fingerprint Based Attendance Systems-A Review. International Research Journal of Engineering and Technology, 3(5), pp. 1166- 1171.

[9] Prince, N., Sengupta, A., \& Unni, M. K (2016). Implementation of IoT Based Attendance System on a Dedicated Web-Server. International Journal of Scientific \& Engineering Research. 7(6), pp. 351- 355.

[10] Ali, N. S., \& Alyasseri, Z. A. A. (2017). Wireless Sensor Network and Web Application Hybrid Scheme for Healthcare Monitoring. Journal of Soft Computing and Decision Support Systems, 4(5), 1-7.

[11] Patel, U. A., \& Swaminarayan Priya, R. (2014). Development of a student attendance management system using RFID and face recognition: a review. International Journal of Advance Research in Computer Science and Management Studies, 2(8), 109-19.

[12] Kumar, Jay, and Amit Kumar. (2016). Automatic Attendance Monitoring and Tracking System Using Bluetooth and Face Identification. International Journal of Advanced Research in Electronics and Communication Engineering, 5(4), pp. 1166-1170.

[13] Patel, R., Patel, N., \& Gajjar, M. (2012). Online students' attendance monitoring system in classroom using radio frequency identification technology: a proposed system framework. International Journal of Emerging Technology and Advanced Engineering, 2(2), 61-66.

[14] Baban, M. H. M. (2014). Attendance checking system using quick response code for students at the University of Sulaimaniyah. Journal of Mathematics and Computer Science (JMCS).

[15] Subpratatsavee, P., Promjun, T., Siriprom, W., \& Sriboon, W. (2014, May). Notice of Violation of IEEE Publication Principles Attendance System Using NFC Technology and Embedded Camera Device on Mobile Phone. In Information Science and Applications (ICISA), 2014 International Conference on (pp. 1-4). IEEE.

[16] Shengli, K., Jun, Z., Guang, S., Chunhong, W., Wenpei, Z., \& Tao, L. (2015). The Design and Implementation of the Attendance Management System based on Radio Frequency Identification Technology.

[17] Arulmozhi, P., Rayappan, J. B. B., \& Raj, P. (2016). The design and analysis of a hybrid attendance system leveraging a twofactor (2f) authentication (fingerprint-radio frequency identification). Biomedical Research.

[18] Azasoo, J. Q., Engmann, F., \& Hillah, K. A. (2014, October). Design of RF based multithreaded RFID student attendance management information system. In Adaptive Science \& Technology (ICAST), 2014 IEEE 6th International Conference on (pp. 1-5). IEEE.

[19] Abas, M. A., Tuck, T. B., \& Dahlui, M. (2014, October). Attendance Management System (AMS) with fast track analysis. In Computer, Control, Informatics and Its Applications (IC3INA), 2014 International Conference on (pp. 35-40). IEEE.

[20] Younis, M. I., Al-Tameemi, Z. F. A., Ismail, W., \& Zamli, K. Z. (2013). Design and Implementation of a Scalable RFID-Based Attendance System with an Intelligent Scheduling Technique. Wireless personal communications, 1-19.

[21] Kuriakose, R. B., \& Vermaak, H. J. (2015, November). Developing a Java based RFID application to automate student attendance monitoring. In Pattern Recognition Association of South Africa and Robotics and Mechatronics International Conference (PRASA-RobMech), 2015 (pp. 48-53). IEEE.

[22] Chiagozie, O. G., \& Nwaji, O. G. (2012). Radio frequency identification (RFID) based attendance system with automatic door unit. Academic Research International, 2(2), 168.

[23] Benyo, B., Sodor, B., Doktor, T., \& Fördös, G. (2012, April). Student attendance monitoring at the university using NFC. In Wireless Telecommunications Symposium (WTS), 2012 (pp. 1-5). IEEE.

[24] Soewito, B., Gaol, F. L., Simanjuntak, E., \& Gunawan, F. E. (2015, August). Attendance system on Android smartphone. In Control, Electronics, Renewable Energy and Communications (ICCEREC), 2015 
International Conference on (pp. 208-211). IEEE.

[25] Liang, X. Q., Li, W. Y., \& Lu, T. C. (2017, August). A Study of the Multi-Organization Integrated Electronic Attendance System. In International Conference on Intelligent Information Hiding and Multimedia Signal Processing (pp. 53-61). Springer, Cham.

[26] Yadav, R., \& Nainan, S. (2014). Design of RFID based student attendance system with notification to parents using GSM. International Journal of Engineering, 3(2).

[27] Arbain, N., Nordin, N. F., Isa, N. M., \& Saaidin, S. (2014, December). LAS: Web-based laboratory attendance system by integrating RFIDARDUINO technology. In Electrical, Electronics and System Engineering (ICEESE), 2014 International Conference on (pp. 89-94). IEEE.

[28] Tiwari, A. S., Tiwari, A. S., Ade, N. M., Sheikh, S., Patel, N. R., \& Khan, A. R. (2014, January). Optimized design of student attendance system using rfid. In International Conference on Machine Learning, Electrical and Mechanical Engineering (pp. 8-9).
[29] Pranali, S., Mayuri, S., Manisha, T., \& Varsha, J. (2015). An Intruder Tracking and Attendance Monitoring System Using Mifare Technology.

[30] Farpat, S., VYAS, D., \& Chavan, S. (2015). Monitoring Of Attendance Using RFID and GSM Technology, 3(2), pp. 1-8

[31] M.Praveen Kumar and B.Mani Kumar. (2015). RFID based Attendance monitoring system Using IOT with TI CC3200 Launchpad. International Journal \& Magazine of Engineering, Technology, Management and Research, 2(7), pp. 1465-1467.

[32] Srinidhi, M. B., \& Roy, R. (2015, January). A web enabled secured system for attendance monitoring and real time location tracking using Biometric and Radio Frequency Identification (RFID) technology. In Computer Communication and Informatics (ICCCI), 2015 International Conference on (pp. 1-5). IEEE.

[33] Ya'acob, N., Adnan, S. F. S., Yusof, A. L., Azhar, A. E., Naim, N. F., Mustafa, N., \& Mahmon, N. A. (2016). RFID lab management system using Arduino microcontroller approach associate with webpage. 